\title{
Returnees and their neighbors: Migration of the Romanian Roma, networks, social distance, and local development ${ }^{1}$
}

\author{
Stefánia Toma - László Fosztó \\ https://doi.org/10.51624/SzocSzemle.2018.4.2 \\ Manuscript received: 10 September 2018 \\ Modified manuscript received: 15 December 2018. \\ Acceptance of manuscript for publication: 21 December 2018
}

\begin{abstract}
Migration has a significant impact on the home communities of the migrants through financial and social remittances. There is an ongoing debate about the effects of migration on local development between proponents of approaches inspired by "development optimism" on the one hand, and those that are focused more on the negative consequences. Our study is focused on the ways mobile Roma are repositioning themselves within two ethnically mixed localities in Transylvania. Returnees take advantage, reorient and navigate between local social categories, challenging them to rely on the resources at their disposal to improve the situation of their families and communities. Social networks facilitate migration and also serve as support for the renegotiation of social categories at home. We distinguish between two main patterns of network development. On the one hand there are localities where network ties crosscut ethnic boundaries and facilitate intense exchanges and communication between different segments of local society. In the other case, network ties tend to be tight between members of the same ethnic category, but ties that cut through ethnic boundaries remain weak. We discuss the implications of these patterns for the local development paths of the home localities of the migrants.
\end{abstract}

Keywords: Migration, Networks and Categories, Social Distance, Local Development, Roma in Romania

\section{Introduction}

The demise of the socialist regimes in Eastern Europe and the expansion of the European Union in the region created the conditions for a new wave of migration. Emerging east-west migration have contributed to a renewed scholarly and public discussion not only about the future of the EU as a political and social project, but also about the impact of massive population mobility on social inequality and development in the eastern part of the continent. During these debates,

1 The research leading to the present publication results from the research effort "MigRom - The Immigration of Romanian Roma to Western Europe: Causes, effects, and future engagement strategies," a project funded by the European Union's Seventh Framework Programme under the call "Dealing with diversity and cohesion: the case of the Roma in the European Union" (GA319901). We are grateful to two anonymous reviewers as well as to Judit Durst and Krisztina Németh for their editorial comments and patience. 
the demographic and socioeconomic development of the states on the eastern periphery of the EU, Romania among them, is rarely presented in an optimistic light (Horváth - Kiss 2016).

This developmental pessimism dominates most of the analyses regarding the migration and return of the most impoverished Eastern European social groups, Roma among them. A large part of the scholarly literature concerning the migration of Roma highlights the limitations of European citizenship regarding the effective protection of the rights of the most vulnerable during their sojourns within the European Union (van Baar, Ivasiuc, and Kreide 2019), and demonstrates that their social mobility is stalled in their destinations and that their exclusion continues or even intensifies after they return home (Creţan - Powell 2018). Moreover, there is cumulative evidence of the failure of policies promoted by the EU to combat discrimination and facilitate social inclusion or community development among the Roma "on the ground" in the context of their home countries (FRA 2018). Most of this literature highlights how persisting social exclusion of the Roma hinders socioeconomic development in Romania and has only contributed to the "racialization" of the Roma (see Ylldı - De Genova 2018).

In this article we challenge the approaches that argue that the intra-European mobility of the Roma has only worsened their exclusion by showing that the effect of mobility is multidimensional and goes beyond mere economic changes and exchanges. Focusing mostly on a comparative discussion of two ethnically mixed localities in Transylvania, we argue that migration and return have far more diverse local effects due to a specific combination of economic and non-economic factors that are able to produce social transformations. We highlight the role of non-economic factors, such as hierarchically organized ethnic categories, the social distance between these categories, and the existence or scarcity of social networks and exchanges that crosscut ethnic boundaries, in order to show how they also shape the different paths of local development. We propose a typology of the development paths in ethnically mixed localities, aiming at creating more nuanced approach to addressing changes in social relations induced by migration. The empirical data presented here emerged from the MigRom research project (see Matras - Leggio 2018).

The paper is structured as follows: first, we present the research design and provide a short literature review about the existing research and quest for conceptual tools for our analysis. We then introduce the data from the field-sites, followed by a discussion of the findings.

\section{Research design and methods}

The ethnographic and statistical data presented in this study come from the MigRom project. As the Romanian partner of this collaborative project we selected five localities - three medium-size towns and two villages, covering different 
regions of Romania - in order to investigate the local effects of migration of the Roma communities. We employed mixed methodology, using both quantitative (surveys) and qualitative (ethnographic fieldwork and conducted qualitative interviews) research between 2014 and 2016 in all the localities.

We designed a survey using two questionnaires. First, we used a household survey to elicit basic demographic data and present questions related to the migration experiences. This form was used in as many households as possible. ${ }^{2}$ Second, on a sample of Roma households we applied a more detailed questionnaire about income types and spending in the households, remittances, utilities, housing conditions, migration history and intentions, destination countries, social networks, and relations with local administration. This questionnaire was carried out on a sample of the majority population in the two villages as a control group - including an additional block of questions on social distance, everyday attitudes and contact between members of different ethnic groups. The fieldwork for the survey was organized during the winter months (November-February) to ensure we could reach migrants involved in circular migration. We worked closely with both local Roma and non-Roma research assistants at every phase of the research. We followed the same principles as in the case of the majority sample regarding eliciting attitudes towards the Roma. ${ }^{3}$ This study is focused on the two villages from Transylvania.

\section{Literature review}

While there are recurrent discussions about the migration-development nexus and different approaches fluctuate between developmental optimism and pessimism, it is important to identify how additional resources brought in by mobility are distributed and invested (de Haas 2010). It is worth considering the classic example of the half-full or half-empty glass, and identifying how local society pours and filters "the liquid" (material and non-material resources) through the channels of social relations. Development, broadly defined, is the cumulative result of social changes through which improvements in the economic and social context can be observed at a local level, and in which different types of resources are mobilized. The local articulation of social change depends both on local social divisions and the context in which it occurs. Ethnic categories historically play an important role in the production and maintenance of the inequalities between different segments of local society (Roma/local majority).

2 In the villages we tried to undertake a community census, but we can only approximate the size of the Roma population in both cases as we could not reach those households whose members were abroad for a longer period of time. Thus we collected data on 1041 persons in Baratca and 672 in Bighal. In our reports and articles we use pseudonyms for the localities to protect the identity of the communities.

3 We are grateful to our research assistants and research participants in all localities for the help they provided during these months and for accepting us into their day-to-day lives. 
In terms of conceptualizing the role of categories in producing and maintaining social inequality, the work of Charles Tilly has inspired recent theoretical discussions. Tilly summarized the structure of the main elements of his relational theory of inequality ${ }^{4}$ in a short article published in Anthropological Theory:

Controllers of valuable resources who are pursuing exploitation or opportunity hoarding commonly invent or borrow categorical pairs, installing them at dividing lines between greater and lesser beneficiaries from products of those resources. In this broad sense, inequality by gender, race, ethnicity, class, religion, citizenship, lineage, and many other categorical principles follows common causal patterns. Explanation of inequality and its changes must therefore concentrate on identifying combinations and sequences of causal mechanisms - notably exploitation, opportunity hoarding, emulation, and adaptation - within episodes of social interaction. (Tilly 2001: 368)

For the purpose of our study, as well as more generally for migration studies, the concept of opportunity hoarding provides an important theoretical point of entry. Rogers Brubaker suggested in his critical review of Tilly's theory that opportunity hoarding by "categorical bounded networks" should be further refined:

[T] he notion of "categorically bounded networks" conceals a tension, joining elements with quite different logics that may work separately in practice. Categories are defined by commonality, networks by connectedness. Categories are classes of equivalent elements; networks are sets of relationships. Category members are not necessarily connected to one another, and relationally connected people need not belong to the same category. Definitionally positing "categorically bounded networks" as the agents of opportunity hoarding elides the difference between network-based and category-based modes of social closure and forecloses the question of whether, when, and how categories of difference are involved in insiders' efforts to monopolize goods and opportunities. (Brubaker 2015: 16)

Many forms of categorical exclusion were delegitimized in most of the societies of the Western world (and beyond) during the second part of the twentieth century; formal social mechanisms which produce or maintain inequality based on categories like sex, ethnicity/race, and religion are illegal in all European countries today. However, one particular form of categorical discrimination has remained largely unchallenged: this is discrimination based on citizenship (Brubaker 2015: 45).

A large part of the literature about the recent mobility of the Roma has its focus at this level: it discusses issues connected to the process of European enlargement, the extension of EU citizenship, and the consequence of this in core EU countries. Several thematic issues of journals and an edited volume have covered the issues of

4 A full elaboration of this theory may be found in Tilly's book Durable Inequality (1998). 
the emergence of European policies and the local context of Roma migration with particular focus on the destination countries (Clough Marinaro - Sigona 2011; Sigona - Vermeersch 2012; Nedelcu - Ciobanu 2016; Ylldız - De Genova 2018; Asztalos Morell, Greenfields - Smith 2018; van Baar, Ivasiuc - Kreide 2019). There is broad agreement that the European Union follows the blueprint of a "neoliberal" project (Sigona - Trehan 2009), a logic that on the one hand promotes a free flow of capital and labour, but also builds obstacles against the poor and underprivileged to prevent their mobility. Moreover, these populations (in particular the Roma and Muslims) are racialized, and their exclusion is more severe than before (van Baar 2017).

Case studies demonstrate that, along with the extension of EU citizenship, the categorization of citizens is undergoing changes that render large numbers of migrants undesirable in their destination countries. However, these processes of categorization do not stop Roma from migrating and this has led Nicolas De Genova, one of the most fiercely critical voices of this citizenship regime, to concede:

[W] are reminded that, no matter how abject their citizenship, and no matter how effectively un/free their mobility, as EU citizens, many Roma migrants nonetheless appropriate their putative right to 'free movement' and migrate in order to realize their various aspirations and ambitions for a way of life free from the asphyxiating constraints of their racial subjugation 'at home.' (De Genova 2019: 38)

Local studies approach the mobility of "new EU citizens" from a different angle and focus on the categorization and repositioning strategies observable on the ground within the communities. They reveal that Roma individuals and communities do not subject themselves passively to the home conditions, but rather use their mobility to challenge and overcome local categorical hierarchies. Similarly to these ethnographic case studies from Transylvania (Cingolani 2012; Anghel 2016; Voiculescu 2004; Kinda 2011; Peti 2017; Szabó 2018) and elsewhere (see the thematic double-issue of Intersections edited by Durst and Nagy 2018), we describe the agency of the migrants, and their strategies of resisting and challenging the existing local order in their quest to improve living conditions. Repositioning strategies take many forms, from more isolated and individual to more widespread within the home communities (Szabó 2018: 220; Kinda 2011; Kiss - Kiss 2017; Kiss 2015), and can be accompanied by challenges to the local hierarchy, the crossing of ethnic boundaries, or exiting altogether and migrating permanently (Anghel, forthcoming).

One particular set of repositioning strategies triggers spontaneous residential desegregation processes. Using resources from their migration, Roma acquire houses or plots, move to central locations in the localities, or build their own large houses. Similar developments occur among ethnic Romanian migrants, since they also move to more prestigious spaces and build bigger houses. However, the case 
of Roma houses or "palaces" is peculiar, since they attract much criticism. Based on their urban fieldwork in Timișoara, Reșița, and two other smaller settlements in the Banat, Crețan and Powell argue that Roma, despite being "wealthy" and owning large houses in the city centre, still cannot escape group stigmatization (Creţan and Powell 2018). Others view the conspicuous architecture as a way for these Roma to formulate claims to citizenship (Tomlinson 2007), while others wonder if these constructions become "magnets for hate" of the local majority (Nemeth and Gianferro 2009). It is noteworthy that "Roma palaces" are not randomly scattered but clustered in localities distributed all over Romania (Gräf 2008). Their emergence is connected to the internal structures and ideas within the particular Roma community (Tesăr 2016; Benarrosh - Orsoni 2015) and their relationship to the local majority.

Speaking about the role of networks, Maria-Carmen Pantea highlights their importance as informal "migration infrastructure" (Pantea 2013). Péter Berta focused on a highly mobile Roma group and their ways of accumulating relational capital and cultivating networks that enable them to practice intermediary commerce (Berta 2014). Similarly, the migrant Roma described by Cătălina Tesăr (Tesăr 2011; Tesăr 2016) use their mobility abroad to maintain their cultural autonomy in the communities of origin. These later cases could be seen as coming closest to what Charles Tilly called "categorically bounded networks;" however, in these cases the economic strategies of the groups rely on maintaining ties outside the community. Roma moving between different locations manage to keep apart spheres of production and consumption; in their productive activities they depend on outsiders, but they still celebrate their putative independence in the spheres of consumption and ritual (Stewart 1997).

There is a set of network ties that systematically crosscuts ethnic categories: these are informal relations with particular members of the local majority who represent or work within local institutions. Often, the effective operation of social rights depends on these networks. In addition, institutions legalize dwellings, issue permits, or extend communal infrastructure, which activities are crucial in creating the legal frame for local development.

Local networks maintain the heterogeneity of the population within the broad category of citizenship. These are framed by different local institutions, in particular churches, as already described (Fosztó 2003; Kinda 2007; Fosztó 2009), while the translocal role of these networks during migration has also been highlighted (Peti 2017; Lipan 2017).

In our previous publications (Toma - Fosztó 2018; Toma, Tesăr, and Fosztó 2018) we described and analyzed the emergence of migration among the Roma segments of population inhabiting ethnically mixed localities in Romania. The migration of the Roma in increased numbers started later than the migration of other Romanians. Local ethnic relations and, in particular, the social distance between Roma and the majority has an effect on how migration networks develop 
(Toma and Fosztó 2018). Taking our argument one step further, we show below how the local context can shape the effects of return. We argue that in localities with rather heterogeneous populations, as is often the case in Transylvania, shifting networks and the negotiation and re-negotiation of local ties and categories should be discussed as part of the local development process.

\section{The communities in transformation}

In order to analyze the role of the categories and networks that produce and maintain social inequality during the migration process we will look at the case of two field-sites. Starting from the processes described by Charles Tilly as opportunity hoarding through "categorical bounded networks," we problematize the relationship between networks and categories following the suggestion by Rogers Brubaker. Our empirical case exemplifies the dynamic processes that not only rely on the existing categorical divisions within the localities, but also shape the potential development paths of the communities of origin. In one of the cases the developmental effect of migration fosters more convergent social categorization, while in the other case it reinforces more divergent interpretations that challenge the preexisting categories. Accordingly, social networks develop either in a more encompassing manner or narrow down along categorical distinctions (represented by the vertical axis of the figure below). The migration-induced transformations can produce rather competitive relations, but can also encourage cooperation. Here we understand competition and cooperation in a broad sense that is not limited to economic behavior; it rather represents a general attitude of acceptance or contestation of locally imposed symbolic hierarchies and categories (represented by the horizontal axis).

Figure 1.: Migration-induced development paths in ethnically mixed localities

\section{Convergent}

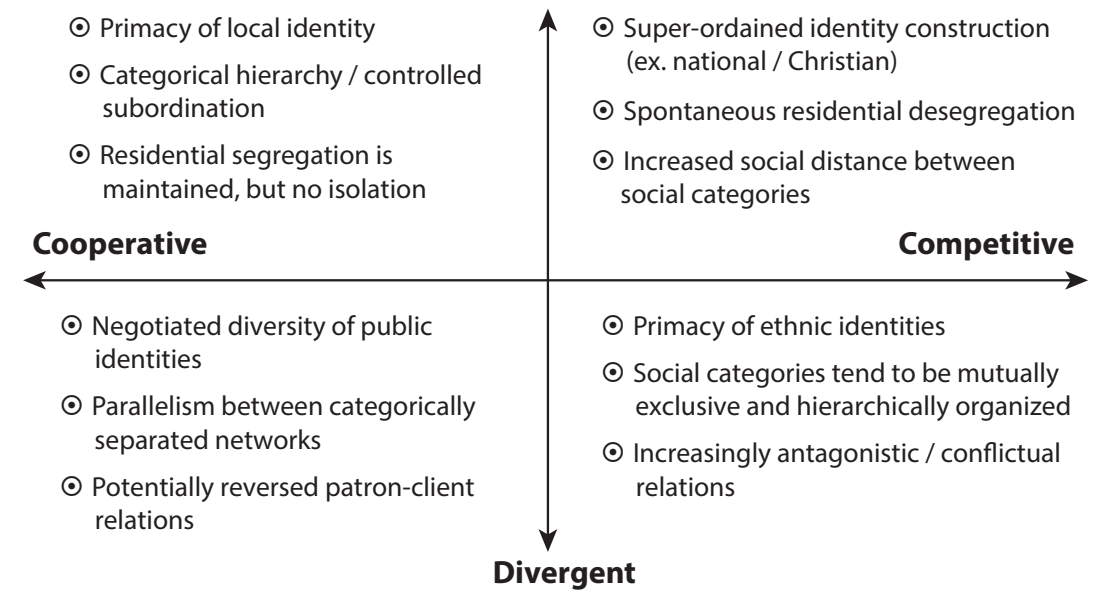


Baratca and Bighal are villages of between 3000 and 3500 inhabitants. Hungarians form the dominant local majority in both cases and there is a significant Roma population (about 35\% of the total inhabitants of Baratca and around $20 \%$ of Bighal). The Roma in both localities are engaged in rather intense international mobility. Most of the Hungarians in Baratca belong to the Lutheran Church, while Roma are traditionally Orthodox Christians but have increasingly converted to Pentecostalism in recent decades. They speak exclusively Romanian as their native tongue. In Bighal most Roma are native Romani speakers, also proficient in Hungarian and Romanian. Traditionally, Roma and Hungarians are members of the Reformed (Calvinist) Church, but more recently membership of neo-protestant groups (i.e., Pentecostal and Baptist) has increased among the Roma community.

The localities are situated in relatively well-developed counties in Transylvania - Baratca in Brașov county and Bighal in Sălaj county (Benedek, Cristea, and Szendi 2015: 25-26; Teșliuc, Grigoraș, and Stănculescu 2016:274). Nevertheless, according to the Atlas of Rural Marginalized Areas the rate of marginalization of above $24 \%$ in Baratca corresponds to severe marginalization, while in Bighal the rate of marginalization falls between 6.1 and $12 \%$, which roughly corresponds to the county average. ${ }^{5}$

Our field research confirmed these data.

\section{The competitive architecture of Baratca}

When approaching Baratca by car or by train one inevitably observes the poor and segregated area on the fringe of the hill with scattered one-room wooden or cob buildings. There are no paved streets leading to the hill settlement, and practically no access to basic infrastructure (running water, electricity, a sewage system). There are also some newly renovated or unfinished and relatively bigger houses on the main (national) road. These are houses that used to be the property of local Hungarians, bought by better-off Roma families who managed to save enough money by working abroad more or less regularly.

The first interviews revealed that Roma started to migrate due to the declining local formal or informal employment opportunities. They used to be employed as non-specialized or qualified workers before 1989 in nearby industrial centers, but these dissolved soon after their privatization following 1990. Others were agricultural workers, who now occasionally rent plots of land from the villagers and garden them. Approximately $60 \%$ of the surveyed households (households number 240 in total in Baratca) had one or more household members working abroad after 2007, while none of them had migration experience before that year.

5 These indicators of marginality are built by using data about human capital (such as education level, health, and family size or number of children), employment situation and housing situation (Teșliuc, Grigoraș, and Stănculescu 2016, p. 21). 
We documented the case of Skinny during our fieldwork in the village. This case can be seen as an example of a successful migrant career:

Skinny, a young Roma man, was the pioneer of looking for opportunities in Great Britain, and considered that it was more convenient and worthwhile for the family to stay together there, so he took his whole family. Slowly, through him more and more people from the extended family, and later from the community, started to make use of his network relations in London. He became the job intermediary for this network, invested in renting accommodation in London and then sub-renting to his co-villagers. Soon, the demand grew considerably, therefore the transportation businesses invested in regular bus connections between the village and London and Paris, ${ }^{6}$ making it easier for the locals to travel, but also to send smaller or bigger packages.

Most of the investments go into buying consumer goods, making improvements to homes, or acquiring new houses. For many families these are the urgent demands, while only a few families have managed to use financial remittances to start a business. ${ }^{7}$ One family invested in agriculture, renting plots in the village or in the nearby village and buying 50 sheep. Some other families invested in opening small shops ("magazin mixt") in the close vicinity of the segregated neighborhood, to the deep discontent of a middle-aged, non-Roma woman who used to have a similar small shop right in the center of the village. She complained that after the opening of large shopping malls with a huge diversity of merchandise, the local majority population changed their shopping habits, buying everything in the city. Before migration started, she could rely on the shopping demand of the Roma, but now "those five Gypsy shops have taken over all the clients." They have the relative advantage of being closer to the settlement, and make offers adjusted to the needs of clients and offer informal credit to reliable customers.

Some admire the skills that the Roma have acquired during their trips abroad while working in constructions. These masonry skills are most visible in the segregated neighborhood where huts are gradually being replaced with small, but modernized brick houses. This is the neighborhood where change is most noticeable for the locals, as the appearance of new buildings contradicts the stereotype of the Roma as negligent with their environment. Consequently, it is recognized that the mobility of Roma produces changes in local society through their making use of social and financial remittances. We may expect that these

6 We should mention here that the migration network to Paris has a different development history.

7 Describing pessimistic views of migration and development studies, de Haas (2010:236) mentions that there is a widespread tendency to artificially differentiate between "conspicuous consumption" and non-productive spending of remittances and productive investment of money. Nevertheless, Conway \& Cohen (1998:28) underlined that in the case of poor households/ communities the importance of consumption expenditure should not be underestimated. Similarly, investment in health and education should also be defined as productive investment. 
changes go beyond the immediate familial context, impacting the broader community, including non-migrants (Taylor - Dyer 2009; Elrick 2008).

They come home with quite a good amount of money, they buy houses and cars here, so you can already see that there is another mentality, they think differently. Of course, there are also those who go and do the same things that they used to do here, begging or stealing, and with this of course they darken the situation of the others (...) For us as a commune and community, I consider that it is a good step that they are going to other worlds so that they can see these other worlds; they come home with a different mentality. (Representative of local institution, an ethnic Hungarian man)

Improvements are apparent not only in terms of the material situation but also in terms of this "different mentality" - what we could call social remittances (Levitt and Lamba - Nieves 2011; Levitt 1998). "Seeing other worlds" is highlighted as an opportunity for learning new things and broadening the perspective when returning home. Another interlocutor explained in more detail the changes she has observed, and even distinguished between segments of the community:

(...) and you can see the difference here in the village as well because they go abroad, and you can see it in the houses. (...) there are two communities... there are the very poor, who do not have anything, but there are also those who are better-off. They have houses following the style they saw abroad, with a large living-room, in which the kitchen is combined with the livingroom - the majority of them have it like that, they have big rooms and bathrooms. So they have [these new living] conditions, and you can look at those who have [such] conditions [and see] that they wash themselves, they aren't like they used to be before. But those who don't want to do this - because there are those who don't want to - they learned this [these earlier habits] and stay like this, [they] have houses of $16 \mathrm{~m}^{2}$ and live even ten persons or even more in a single room. (Representative of institution, ethnic Romanian woman)

Nevertheless, these changes are not perceived equally positively by all segments of local society. The beneficial effect of migration is recognized, but in the meantime the stereotypical representation of "the Gypsies" (what the locals call the local Roma population) is also reiterated. Some Hungarians complain that the Roma families who move to more central spaces in the village "invade the village," ultimately becoming the dominant population. A parallel process is that the increasing number of Roma who declare Romanian ethnicity during the national census make local Hungarians even more anxious, as revealed to us by the local census-taker. Regionally (in Brașov county) Hungarians are a minority and are aware that their local political dominance is rather fragile. The most characteristic response of the majority to the rise in visibility of the Roma and their physical proximity is increased social distance. Our attitude survey revealed 
that more than $60 \%$ of the non-Roma sample from Baratca state that they would not even accept Roma as citizens of the country. Virtually no respondent would accept Roma individuals as family members (1.1\%). This categorical refusal contrasts strongly with results from Bighal: there, roughly half $(48.9 \%)$ of the majority sample expressed a willingness to accept Roma as family members, and not a single respondent said that they should be excluded from Romania (see details in Toma and Fosztó 2018).

\section{Cooperative exchanges in Bighal}

The migration of the Roma in Bighal in Sălaj County follows a rather different path and the effects of return are also different. As the general data show, the rate of marginalization in Bighal is considerably lower than in Baratca, and this fact is apparent immediately when entering the village. On one edge of the village there is a Roma-only settlement, but in a different location there is an ethnically mixed neighborhood. Generally, the locality gives the image of a developing village; at least as concerns public investment into infrastructure. The national road crossing the village is maintained, there are well-groomed green areas, a recently built and enlarged administrative office, and a new kindergarten. Soon one learns that in a relatively short time after a new mayor was elected, even more public money was invested into different domains, also benefiting the segregated Roma community. This settlement, in contrast to Baratca's Roma neighborhood, shows clear signs of planning. It includes rows of relatively bigger houses, and courtyards with fences. There are some gardens with signs of subsistence agriculture. On the margins of this settlement a number of social houses were built during the 1990s as part of a project. One of the buildings functions as a community center that also has public bathing facilities. During the last two years (2016-17), the mayor's office has started to pave the sidewalks in the Roma communities.

Traditionally, the local Roma used to be brick-makers, supplying the market demand of the region. Later, during the socialist period, some of the Roma - while also continuing to produce bricks - were employed in small factories in the nearby towns, while others worked in a local agricultural cooperative or on farms in the west of Transylvania. After the dissolution of the agricultural cooperative and re-privatization of the land, the Roma continued to work on the fields for local owners as day-laborers. Some others found informal employment in construction and in households. The economic crises in the middle of the 2000 s represented a serious setback not only in terms of the job-market, but also of opportunities for investing to earn a more or less regular income. The migration of the Roma started in this period and, similarly to in Baratca, approximately $60 \%$ of households have migration experience abroad following 2007. Nevertheless, a considerably higher percentage of households (87.2\%) declared that they spent money resulting from 
the migration of household members. Thus, they are able to cover most of the basic needs of the family. Many others had the chance to invest in a long-cherished dream, or plan improvements to their houses in the neighborhood (a new room or bathroom, improving the roof of a building, building a fence, or changing the gate of a courtyard, changing windows or doors, connecting to the water and electricity supply or sewerage system).

A wander around the fair (a tradition with roots dating back as early as the fifteenth century) that is traditionally held every first and third Wednesday of the month is a good occasion to feel and experience how migration is a constitutive part of local lives. Although local fairs have declined in national and regional importance, they are still busy events where, beside buying, selling, negotiating or just simply browsing, you can meet with fellow villagers and talk about important things and exchange information. In the usual hubbub, amicable and curious questions are raised regarding the migration and work experience of others. Answers fly around in a casual way that afterwards becomes a good basis for gossip with neighbors or relatives, or formulating appreciative or condemning assessments of one's success or, on the contrary, failure. It was on one of these days that we joined a Roma family (husband and three children), under the leadership of Maria (a woman in her late 30s), going to market to buy the immense amount of vegetables needed for the traditional zacuscă ${ }^{8}$ that is usually prepared for the winter period.

At home the men prepared the vegetables on a stove in the courtyard, and the typical hurly-burly started. Women from the neighborhood (Roma and Hungarians alike) dropped by and stayed for an hour or two to help with cleaning the grilled vegetables. Being late autumn, a period when some of the men were still abroad, the wives of the former were waiting for their return; they discussed new migration routes or opportunities for the coming year. Raising the issue of money was inevitable, as some were concerned about the amount of money their husbands would bring home. Would it be enough to cover their plans for improving their household's lives? Some complained that the hourly wage of seven euros is rather low, and it is not enough to make it worth staying in Italy any longer; others replied that it is still more advantageous and safer to do this than to go to Hungary or the Czech Republic to work in agriculture. The women commented with amazement that a male from the community chooses to stay at home, claiming he considers the former wages too low. Another woman said that in Poland the salaries in the construction industry had also dropped recently. Now her husband receives only 1300 euros/month. They are planning for him to try his luck in Italy next year, hoping that despite the deprecating gossip, salaries are still much higher than in Central-Eastern European countries.

8 A very popular vegetable spread in Romania, variations of which can be found throughout the Balkans and Turkey. 
The women were well informed about migration-related opportunities, networks and risks. They appraise what is worth doing and what would not be good enough for their households. They were planning to invest the money besides the usual spending on daily needs - in building an additional room as the children were growing. The roof of the house also needed improvements. Others wanted to change a fence, or to build a bathroom. Schooling "eats more and more money as the children grow." ${ }^{\prime 9}$ Another woman - the health mediator for the Roma - warned about the negative side of having access to more money from migration: not everybody is careful spending their money; some of the men have serious issues wasting it on gambling machines or have drinking problems. The more they earn, the more they spend on these "stupid things." Locals - Hungarians and Roma alike - are very critical about the way money is spent, both when abroad and after it is bought back home. Irresponsible expenses (spending too much money on expensive food and drink abroad, or gambling) are the target of intense gossip.

\section{Challenging social and ethnic categories}

While in Baratca the main way to display the wealth of the household and success in migration was related to the house - newly built or re-furnished -, or in some cases the launching of a small business, in Bighal the marketplace is a space and occasion for evaluative chats and displaying success. The fair traditionally has a strong interethnic character. It is an arena where the habitual stereotypes of the majority regarding the Roma can be slowly dismantled and deconstructed ("Finally, the children were dressed in clean clothes!"..."You bought a whole sack of eggplants, you must be a good housekeeper!"..."Can they afford a coffeemachine?"..."Ah, your husband is abroad? Good for you!") Nevertheless, the fair is more than simply a moment or a place for displaying status. It is also the place for encounters and where information-exchanges regarding job opportunities happen. ${ }^{10}$ We can contrast the intensity of these local exchanges with the relative isolation of the two communities in Baratca. There, the lack of opportunities for interethnic exchange and shared events that could facilitate these exchanges redirects resources from mobility into more non-verbal displays of status such as the built environment.

In other contexts though, ethnic categorization and stigmatization proves to be more resistant to challenges due to its situational character, as in the following case of racial stigma (Goffman 1963):

One afternoon we were sitting in the kitchen of a local Roma family in Bighal. We discussed experiences of mobility, and how migrants cope with the external

9 The education of children is a recurrent topic in discussions.

10 Informal exchanges of information can help individuals in their job searches, especially if they lack the necessary educational level or professional skills to obtain employment on the formal job market (Sanders et al. 2002: 282). 
perceptions they encounter during their stays abroad. Our host, a jovial Rom in his early forties, told us the story of his interaction with a Hungarian brigade with whom he engages in seasonal migrant labor within Romania, but also occasionally abroad:

We went to Hungary to work on a construction project there. After the work day [had finished] we had a beer together and the Hungarians started to talk to each other, complaining: "If we are at home, in Romania, we are called 'bozgori' by the Romanians [an insulting and derogatory term for Hungarians] so one has to stay silent. When we come here to Hungary, they [the Hungarians from Hungary] call us Romanians. You cannot feel good anywhere. Our host laughed at them: "You see - I do not have this problem. When I am home they call me 'țigan' and that's it. When I am here in Hungary they still call me cigány!"

This episode exemplifies that ethnic and national categories do not offer constant shelter from denigrating ascriptions. Situational stigmatization is not limited to the Roma; others are also subject to stigma, like the Magyars ('Hungarians') from Transylvania in this case. The inconsistencies in these ethno-national categorizations remind them of the social insecurities involved in the mobility process.

This episode can be also a reminder that both groups (Magyars and Roma) are part of a larger political space; they are Romanian citizens within the enlarged European Union. When travelling to Hungary, local Magyars are reminded of their differences, which bring them symbolically closer to the locally rooted categories. Migrating as part of a mixed network has benefits for both Magyars and Roma in terms of sharing the migration experience and being able to closely negotiate their interpretations.

In contrast to this example, migration sustained by ethnically separated networks, as happens in Baratca, increases the divergence in local negotiations of social categories. Mobility unsettles locally rooted social categories in the communities of origin. Returnees challenge the local order and express new forms of belonging, so stay-at-home members of these communities are faced with these challenges. Roma from Baratca can claim "Romanianness" with more confidence after their western European sojourns, since in many cases this identification is accepted as their main identity in the destination context. These claims, validated by their symbolic social ascension within the village, feed into the challenges to the old hierarchy of categories which are perceived by local Hungarians as signs of their growing insecurity within the village.

To make things appear worse, the local effects of the "securitization" of the Roma migrants within the western member states of the EU appear in rather palpable forms.

During out fieldwork, locals told us about an "internationally organized" event within the segregated Roma settlement of Baratca which happened before we 
started our fieldwork. Our field assistant who was involved in this event explained to us that this event was an "awareness raising seminar" organized by the police with the collaboration of their colleagues from England. This seminar took place after the first significant wave of outmigration of Roma from Baratca reached England. Migrants were very visible on the streets of the English city and were begging, so the police forces decided to visit their home community and inform them that they do not welcome begging, and that this activity even borders on illegality in England.

After this first wave, migrants reoriented their activities mainly to construction work and other menial jobs using the opportunities offered by their consolidating migratory networks. Still, local Hungarians perceived the visit of the British police as just more proof of the "illegal activities" of Roma migrants abroad and reinforced their anxiety related to their Roma neighbors.

Another specific form of coping with stigmatization is born-again Christianity after the religious conversion of the Roma to neo-protestant denominations, most typically Pentecostalism. The related churches are present in all field sites, and we could observe their influence in terms of how they offered a new outlook on personal identities, but also by offering entry into a super-ordained category that could transcend local ethic categories and lead to the subordination of the converted.

\section{Development paths: the mobilization of diversity}

Contrasting the developments in these two villages within the broader framework of the processes that can be observed in other localities, we can distinguish between situations where the developmental effect of migration is perceived in a more convergent manner versus places where the influence of migration creates more divergent interpretations that challenge the hierarchy of categories. We can distinguish two dimensions of these developments. On the one hand there are the more cooperative relations maintained by ethnically mixed networks, as opposed to more competitive relations between increasingly separated networks (see Table 1).

Cooperation and competition not only unfolds between individuals, but between different segments / networks of local society, and our observations are focused at this level. When social changes in a locality point in a cooperative-convergent direction, conforming to "others" does not necessarily involve the abandonment of ethnic belonging. It can take the form of negotiating a social identity that is considered adequate and is mutually accepted by each segment of the local community. In this case, being part of an ethnic group and displaying one's ethnic identity can remain at a secondary level of importance. The focus is placed on the well-being and the maintenance of a relatively peaceful coexistence in the locality. This requires that local actors concur regarding aims and priorities, and they can be induced and reinforced by local institutions. Nevertheless, we should underline that, in our 
case, because the local ethnic groups are hierarchically defined, or Roma are even stigmatized, these social relations are never mutually equal.

Table 1. Conditions for cooperative / competitive local social relations and their connection to categorization processes

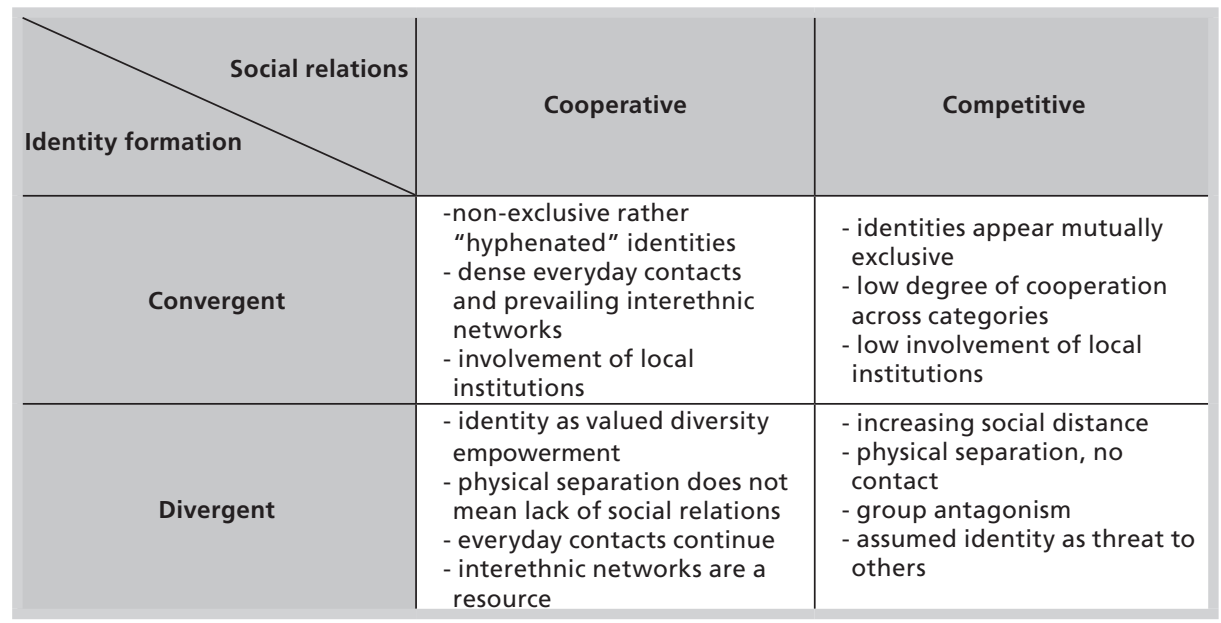

Bighal is a locality that can be best described in terms of cooperative social relations, but there are also signs of developing divergence in the local social categories. Compared to other localities, Bighal emerged as having a high level of acceptance of differences, or in other words, the social distance between different ethnic groups is rather reduced (Toma and Fosztó 2018). This does not mean that we cannot find there a variety of stigmatizing situations and prejudiced attitudes, or even discriminatory behaviors towards the Roma. Still, everyday contacts prevail, Roma accept the public dominance of the Hungarian language, and there are also rather intense symbolic and ritual exchanges mediated by local institutions (for example, common religious denomination). Among our Roma sample, $44.4 \%$ of households have at least one Hungarian godparent. There were no open or violent ethnic conflicts in the village. Migration patterns are defined by these local relationships, involving migration through interethnic networks, often even in ethnically mixed groups.

During the past years, the investment of remittances has contributed to the overall betterment of Roma neighborhoods in Bighal. These developments, complemented by the recent infrastructural investments of the local authority, have contributed to the stability of life in the neighborhood, also meaning that residents did not express a desire to "move out." Living in the neighborhood while in some cases considered a stigmatized territory - does not necessarily 
involve social marginality and segregation, compared to many other cases. One of the possible bridges for overcoming the undeniable reality of living in an ethnically segregated area is becoming an active member of the local community through different channels.

Changes in the ethnic landscape of the locality - including improvements in the Roma neighborhood - are not perceived by the local majority as a threat to their own identity or space. Among those members of the majority who have more or less daily contact with local Roma, relationships are mostly defined in terms of trust and mutual respect and avoidance of conflict; and more than that, belonging to an ethnic group - while remaining important - is of secondary importance. Still, there are signs of diverging identity constructions enacted through cooperation between different groups. The local community - Hungarians and Roma together, with the support of the local administration ${ }^{11}$ - obtained funding for a cultural project that involved the acquisition of "traditional ethnic costumes" for the Roma dance ensemble. Local Roma had no memory and could not find evidence that their ancestors had dressed in ethnically distinguished clothing. Still, everybody agreed that such costumes should be produced for the dancers. This official encouragement of a public display of ethnic difference - even if an invention of new traditions - can be seen as cooperative divergent process. However, it may also be recognized that designing the costume involved a balancing act, since local Romungre do not want to dress in the long colorful skirts of the "more traditional" Corturari Roma who live in the neighboring village. In these cases, for the local Roma (who are Romungre or magyarcigányok), belonging to dual ethnic categories (Roma and Magyar) is not exclusive. Even if there are moments when social/ ethnic identity becomes more divergent and the importance of group membership increases, maintaining contacts is constant and identity construction is rather cooperative, strengthening and reinforcing common belonging.

In contrast, Baratca can be seen as site of competitive social processes involving divergent social categorization. Returnees increasingly challenge the local hierarchical ethnic order, refusing to be seen as stigmatized Roma and channeling their material resources into promoting residential desegregation. The woman shopkeeper we described earlier complained that the relationship between the locals and the Roma had deteriorated lately and they were increasingly alienated from each other, as more and more families move "into the village." An elderly woman, a former primary school teacher, stated that "The mayor is too much of a gentleman. The Gypsies are generally kept tight, but not controlled enough." This "loss of control" also implies to others that they cannot rely on the labour of Roma as before. We overheard the following statement in a bar from a middle-aged and older man who were organizing their work: "We will have problems when

11 The mayor is ethnically Romanian and speaks Hungarian very well. 
we need to load the cart as we do not have neighbors - only the Gypsies." While it may be an implicit assumption that when more difficult jobs arise around the household and an extra hand is needed, you may ask your neighbors to help, in this case, interaction between ethnic groups is increasingly difficult and Hungarians maintain a very high degree of social distance vis-a-vis the Roma.

Roma in Baratca prefer to assume a Romanian identity during the population census and in their public interactions. This makes local Hungarians anxious, as they see their status of local majority threatened. However, this does not mean that the local ethnic Romanians have significantly different attitudes toward the Roma compared to the Hungarians. This feature of the competitive-divergent scenario reminds us of the difficulty of overcoming the consequences of "exclusionary closure:" when members of one ethnic group try to monopolize opportunities and resources for members of their own group (Waldinger - Lichter 2003: 98). Open confrontations also occur: we witnessed a scene at the Social Department of the Mayor's Office: a well-dressed Roma man was informed that his social benefits had been cut because he was working abroad and he no longer qualified for them. He got very angry and raised his voice, annoyed because he was aware that many families who are involved in migration do not lose their benefits. At one point he yelled at the (even angrier) social worker that: "You are not respected, because you don't respect us!" Claiming Romanian national identity is one form of creating respectability.

A closer look into aspects of cooperation and competition within local society and the social categories the different segments negotiate reveals a more complex picture. In Baratca, in addition to the dominant processes along the competitive and divergent dimensions, there are features that could be classified as competitiveconvergent. Roma have not only opened businesses and moved inside the village, but have started to use traditional Hungarian funeral signs (so-called kopjafa) in their own cemetery, adding Romanian language inscriptions to them. However these signs of convergence are not viewed approvingly by the local majority: "They have the nerve to do that!" (Erre van eszük...). The new gates in front of the renovated houses resemble Saxon-style entrances, and local Roma buy furniture from the most expensive company - a Hungarian woman observed with slight jealousy when talking to us. The dominant climate of competition and the perceived threat of "the emerging other" overshadow these incipient signs of convergence or even are seen as illegitimate appropriation. It is not only interpersonal relations that are challenged by the Roma returnees in Baratca.

They pride themselves on their improvements to their homes and repeatedly call on local authorities to expand the communal infrastructure to provide them with services. Those who build their small new brick houses on the top of the hill within the segregated Roma settlement create the relevant installations within their houses in the absence of a proper electricity or water supply and consider 
this the first step towards development, thus it is now it is the turn of the mayor's office to do its part. Whether local authorities decide to follow the path opened by the returnees or prefer to concentrate investment into different areas remains an open question at this moment.

\section{Conclusions}

We started this article by considering that the increased mobility of the Romanians has an important financial and social impact on the home communities. Romanian Roma started to participate in this mobility relatively later, but by the time of our fieldwork in the area we could observe patterns of intense migration and return. We focused on the ways in which mobile Roma communities are repositioning themselves within two ethnically mixed localities in Transylvania. Returnees take advantage, reorient and navigate between local social categories, challenging them by relying on the resources at their disposal to improve the situation of their families and communities. These changes can be described at the level of segments of local society, composed not only of communities but also the networks that facilitate migration and also serve as support for the renegotiation of social categories at home.

We distinguished between two main patterns according to which networks develop. On the one hand there are localities where network ties crosscut ethnic boundaries and facilitate intense exchanges and communication between the different segments of local society. Roma and their non-Roma neighbors often share their migration experience and its interpretation. The other pattern is rather different: network ties tend to be tight between members of the same ethnic category but ties that cut through ethnic boundaries remain weak. The social distance between the categories is kept considerably higher in the second case.

The role networks play is important in the reorientation of the returnees: on the one hand there are attempts at categorical redefinitions that challenge local ethnic hierarchies, or even reverse the old patterns; on the other hand, the order of categories remains or is even reinforced. More precisely, ethnically mixed networks enable individuals to transcend categories in particular types of exchanges. The ways of repositioning of the mobile Roma within local society have consequences for the development paths that local society might take.

Focusing on the non-economic resources that are available (skills, networks, and social categories) the paths of development can be described along two axes: on the one hand, more cooperative vs. competitive social relations and the reinforcement or emergence of more convergent vs. divergent social categories. Along these dimensions we can interpret the different processes generated by mobility which are heterogeneous (i.e., can move in different directions), but some dominant tendencies were distinguished at the two field sites: Baratca seems to be dominated 
by competitive processes coupled with the development of more divergent social categorizations. This is observable in the reconfiguration of the built environment, as more and more returnees renovate and repaint their houses and move to more central areas in the village. This spontaneous residential desegregation goes along with increased social distance between the Roma and their Hungarian neighbors who look anxiously to the future of their local community. At the other field site, Bighal, social development is less divisive; we describe this in terms of cooperative relations and convergent social categorizations. There is no fear of "the other" in this case, and social distance is reduced. There exists a large variety of ethnically mixed encounters, while residential segregation remains in place.

The heterogeneity of the Roma population is an important condition in orienting these development paths. In the two cases that are compared the Roma are rather similar demographically (relatively younger, less educated, and more impoverished) and have different cultural profiles (languages spoken, religious belonging, and ritual exchanges with the non-Roma). Local majorities are also diverse. Taking into account our findings in the other MigRom field sites, the diversity is even wider. In the Transylvanian localities there is a Hungarian majority, but in the southern Romanian site we only find Romanians and different Roma categories. We found that repositioning is present amongst the Hungarians as well (even if identifying this was not the analytical focus). Still, the direction of local development can be interpreted within this framework which offers a chance for a more nuanced interpretation of local effects than previously proposed models of "racialisation" suggest (Ylldiz - De Genova 2018).

The role of local institutions and, in particular, the local administration in shaping the direction of local development must be highlighted. Mayor's offices can take a leading role in the modernization of more underdeveloped parts of the locality and a proactive stance by providing infrastructure and communal services. They can also assist by fostering the most effective investment of the resources that "pour in" from the migration of the less well-off members of the locality. If they can do this consciously, we may hope to see that local migration's half-full glass is not spilled.

\section{References}

Anghel, R. G. (2016): Migration in Differentiated Localities: Changing Statuses and Ethnic Relations in a Multi-Ethnic Locality in Transylvania, Romania. Population, Space and Place, 22 (March): 356-366. doi:10.1002/psp.1925.

Anghel, R. G. (forthcoming): When the Poor Migrate and Return. Status and class repositioning among Romanian Roma. In Anghel, R. G. - Fauser, M. - Boccagni, P. (eds.): Transnational Return and Social Change. Social Hierarchies, Collective Identities and Cultural Capital London: Anthem Press. 
Asztalos Morell, I. - Greenfields M. - Smith, D. M. (2018): Governing Underprivileged Roma Migrations within the EU: Receiving Country Responses and Roma Resilience. Local Economy: The Journal of the Local Economy Policy Unit, 33 (2): 123-126. doi:10.1177/0269094218767329.

Benedek J. - Cristea M. - Szendi D. (2015): Catching up or Falling behind? Economic Convergence and Regional Development Trajectories in Romania. Romanian Review of Regional Studies. 11 (1): 15-34.

Berta P. (2014): Intermediate Trade, Migration, and the Politics of Ethnicity. Economic Strategies among Romanian Gabor Roma. Acta Ethnographica Hungarica, 59 (1): 43-67. doi:10.1556/AEthn.59.2014.1.4.

Brubaker, R. (2015): Grounds for Difference. Cambridge, MA: Harvard University Press.

Cingolani, P. (2012): Near or Far: Daily Life, Migration, and Symbolic Boundaries between Roma and Gagè in Romania. In Buttino M. (ed.) Changing Urban Landscapes. Eastern European and Post-Soviet Cities Since 1989. Roma: Edizioni Viella, 123-151.

Clough Marinaro, I. - Sigona, N. (2011): Introduction. Anti-Gypsyism and the Politics of Exclusion: Roma and Sinti in Contemporary Italy. Journal of Modern Italian Studies, 16 (5): 583-589. doi:10.1080/1354571X.2011.622467.

Conway, D. - Cohen, H. J. (1998): Consequences of Migration and Remittances for Mexican Transnational Communities. Economic Geography, 74 (1): 26-44. doi:10.1111/j.1944-8287.1998.tb00103.x.

Creţan, R. - Powell. R. (2018): The Power of Group Stigmatization: Wealthy Roma, Urban Space and Strategies of Defence in Post-Socialist Romania. International Journal of Urban and Regional Research, 42 (3): 423-441. doi:10.1111/14682427.12626.

De Genova, N. (2019): The Securitization of Roma Mobilities and the Re-Bordering of Europe. In van Baar, H. - Ivasiuc, A. - Kreide, R. (eds.): The Securitization of the Roma in Europe. Cham: Palgrave Macmillan, 29-44. doi:10.1007/978-3319-77035-2_2.

de Haas, H. (2010): Migration and Development: A Theoretical Perspective. International Migration Review, 44 (1): 227-264. doi:10.1111/j.17477379.2009.00804.x.

Durst, J. - Nagy. V. (2018): Transnational Roma Mobilities. The Enactment of Invisible Resistance. Intersections. East European Journal of Society and Politics, 4 (2): 3-16. doi:10.17356/ieejsp.v4i2.466.

Elrick, T. (2008): The Influence of Migration on Origin Communities: Insights from Polish Migrations to the West. Europe-Asia Studies, 60 (9): 1503-1517. doi:10.1080/09668130802362243.

Fosztó, L. (2003): Szorongás és megbélyegzés: a cigány-magyar kapcsolat gazdasági, demográfiai és szociokulturális dimenziói. In Bakó, B. (ed.): Lokális 
világok. Együttélés a Kárpát-Medencében. Budapest: MTA Társadalomkutató Központ, 83-107.

Fosztó, L. (2009): Ritual Revitalisation after Socialism: Community, Personhood, and Conversion among Roma in a Transylvanian Village. Halle Studies in the Anthropology of Eurasia. Berlin: LIT Verlag.

FRA (2018): A Persisting Concern: Anti-Gypsyism as a Barrier to Roma Inclusion. Luxemburg: Publications Office of the European Union.

Goffman, E. (1963): Stigma: Notes on the Management of Spoiled Identity. Englewood Cliffs, N.J.: Prentice-Hall, Inc.

Gräf, R. (2008): Palatele țigănești. Arhitectură și cultură. ISPMN Working Papers, Nr. 9. Cluj-Napoca: ISPMN.

Horváth, I. - Kiss, T. (2016): Depopulating Semi-Periphery? Longer Term Dynamics of Migration and Socioeconomic Development in Romania. Demográfia English Edition, 58 (5): 91-132. doi:10.21543/DEE.2015.4.

Kinda, I. (2007): Felekezeti és kulturális disszimiláció egy orbaiszéki falu cigányainál. In Ilyés, S. - Pozsony, F. (ed.): Lokalitások, határok, találkozások. Tanulmányok erdélyi cigány közösségekről. Kriza János Néprajzi Társaság Évkönyve 15. Kolozsvár: Kriza János Néprajzi Társaság, 153-171.

Kinda, I. (2011): Mobilitate socială și linii de forță ale economiei în viața romilor cărămidari. In Toma S. -Fosztó, L. (ed.): Spectrum. Cercetări sociale despre romi. Cluj-Napoca: Editura Institutului pentru Studierea Problemelor Minorităţilor Naţionale / Kriterion, 367-383.

Kiss, T. (2015): Az etnikai kasztrendszer múködése és bomlása egy székelyföldi nagyközségben. Magyar Kisebbség, 20 (3-4): 13-66.

Kiss, T. - Kiss, D. (2017): A Tanyától az Új Tanyáig. Etnikai átrétegződés és klasszifikációs küzdelem egy partiumi faluban. Regio 25 (2): 51-99. doi:10.17355/rkkpt.v25i2.161.

Levitt, P. (1998): Social Remittances: Migration Driven Local-Level Forms of Cultural Diffusion. The International Migration Review, 32 (4): 926-948.

Levitt, P. - Lamba-Nieves, D. (2011): Social Remittances Revisited. Journal of Ethnic and Migration Studies, 37(1): 1-22. doi:10.1080/1369183X.2011.521361.

Lipan, S. (2017): The Interplay between Ethnic and Religious Frontiers: The Case of Repented Roma Migrants Living in a Belgian City. The Romanian Journal of Society and Politics, 12(1): 53-78.

Matras, Y. - Leggio, D. V. (eds.) (2018): Open Borders, Unlocked Cultures Romanian Roma Migrants in Western Europe. London and New York: Routledge.

Nedelcu, M. - Ciobanu, R. O. (2016): Les Migrations Des Roms Roumains En Europe. Revue Européenne Des Migrations Internationales, 32 (1): 7-17.

Nemeth, D. - Gianferro, C. (2009): Prestige Mansions of the Affluent European Roma: Magnets for Hatred? In Dayton, Ohio: Proceedings on CD by the East Lakes Division of the American Association of Geographers Conference. 
Pantea, M. C. (2013): Social Ties at Work: Roma Migrants and the Community Dynamics. Ethnic and Racial Studies, 36 (11): 1726-1744. doi:10.1080/0141 9870.2012.664282.

Peti, L. (2017): Migráció és pünkösdizmus egy kelet-moldvai kolduló roma közösségben. Erdélyi Társadalom, 15 (1): 57-80.

Sanders, J. - Nee, V. - Sernau, S. (2002): Asian Immigrants' Reliance on Social Ties in a Multiethnic Labor Market. Social Forces, 81 (1): 281-314. doi:10.1353/sof.2002.0058 Sigona, N. - Nidhi T. (eds.) (2009): Romani Politics in Contemporary Europe: Poverty, Ethnic Mobilization, and the Neoliberal Order. New York: Macmillan.

Sigona, N. - Vermeersch, P. (2012): Editors' Introduction. The Roma in the New EU: Policies, Frames and Everyday Experiences. Journal of Ethnic and Migration Studies, 38 (8): 1189-1193. doi:10.1080/1369183X.2012.689174.

Stewart, M. (1997): The Time of the Gypsies. Boulder: Westview Press.

Szabó, Á. T. (2018): Local and Global Contexts, Individual Experiences in Labour: Poor Roma at Home and Abroad. A Case from Transylvania, Romania. Local Economy: The Journal of the Local Economy Policy Unit, 33 (2): 207-223. doi:10.1177/0269094218762345.

Taylor, J. E. - Dyer, G. A. (2009): Migration and the Sending Economy: A Disaggregated Rural Economy-Wide Analysis. The Journal of Development Studies, 45 (6): 966-989. doi:10.1080/00220380802265553.

Tesăr, C. (2011): „Ţigan bun tradiţional” în România, cerşetor de-etnicizat în străinătate. Politici ale re-prezentării publice și etica muncii la romii cortorari. In Toma, S. - Fosztó, L. (eds.): Spectrum : Cercetări Sociale Despre Romi. ClujNapoca: Editura Institutului pentru Studierea Problemelor Minorităţilor Naţionale, 281-312.

Tesăr, C. (2016): Houses under Construction: Conspicuous Consumption and the Values of Youth among Romanian Cortorari Gypsies. In Brazzabeni, M. M. Cunha, I. - Fotta, M. (eds.): Gypsy Economy: Romani Livelihoods and Notions of Worth in the 21st Century. New York: Berghahn Books, 181-200.

Teșliuc, E. -Grigoraș,V.-Stănculescu, M.S.(eds.) (2016): The AtlasofRural Marginalized Areas and of Local Human Development in Romania. Bucharest: Ministry of Labour, Family, Social Protection and Elderly Persons: The World Bank.

Tilly, C. (2001): Relational Origins of Inequality. Anthropological Theory, 1 (3): 355-372. doi:10.1177/14634990122228773.

Toma, S. - Fosztó, L. (2018): Roma within Obstructing and Transformative Spaces: Migration Process and Social Distance in Ethnically Mixed Localities in Romania. Intersections. East European Journal of Society and Politics, 4 (3): 57-80.

Toma, S. - Tesăr, C. - Fosztó, L. (2018): Romanian Roma at Home: Mobility Patterns, Migration Experiences, Networks, and Remittances. In Matras, Y. Leggio, D. V. (eds.): Open Borders, Unlocked Cultures: Romanian Roma Migrants in Western Europe. London - New York: Routledge, 57-82. 
Tomlinson, E. (2007): The 'Palaces' of the Romanian Roma: A Claim to Citizenship. Traditional Dwellings and Settlements Review, 19 (1): 77-90.

van Baar, H. (2017): Evictability and the Biopolitical Bordering of Europe. Antipode, 49 (1): 212-230. doi:10.1111/anti.12260.

van Baar, H. - Ivasiuc, A. - Kreide, R. (2019): The European Roma and Their Securitization: Contexts, Junctures, Challenges. In van Baar, H. - Ivasiuc, A. - Kreide, R. (eds.): The Securitization of the Roma in Europe. Cham: Palgrave Macmillan, 1-25. doi:10.1007/978-3-319-77035-2_1.

Voiculescu, C. (2004): Temporary Migration of Transylvanian Roma to Hungary. In Pop, D. (ed.): New Patterns of Labour Migration in Central and Eastern Europe. Cluj-Napoca: AMM Design, 148-166.

Waldinger, R. D. - Lichter, M. (2003): How the Other Half Works: Immigration and the Social Organization of Labor. Berkeley: University of California Press.

Yıldız, C. - De Genova, N. (2018): Un/Free Mobility: Roma Migrants in the European Union. Social Identities, 24(4): 425-441. doi:10.1080/13504630.2017.1335819. 